\title{
Business Environment in South Asia: Foreign-Owned Firms' Perspectives
}

\author{
Rahim Quazi ${ }^{1}$, Sudhir Tandon ${ }^{1}$ \\ ${ }^{1}$ College of Business, Prairie View A\&M University, Prairie View, Texas, USA \\ Correspondence: Rahim Quazi, College of Business, Prairie View A\&M University, Prairie View, Texas 77446, \\ USA.
}

Received: April 30, 2018

Accepted: May 16, $2018 \quad$ Online Published: June 5, 2018

doi:10.5539/ibr.v11n7p1

URL: https://doi.org/10.5539/ibr.v11n7p1

\begin{abstract}
This paper studies the foreign-owned firms' (hereinafter, FOFs) perspectives about selected indicators of business environment in four South Asian countries - Bangladesh, India, Pakistan and Sri Lanka. For the last few decades, these countries have eagerly sought to increase the inflow of foreign capital. Using the World Bank's Enterprise Survey 2017 data, this study identifies political instability, poor infrastructure, and pervasive corruption as the three biggest obstacles that FOFs face in their business operations in these countries. The other obstacles include inadequately educated workforce, customs and trade regulations, crime, theft and disorder, tax administration, business licensing and permits, and access to finance. This study also finds that since 2007 the business environment for FOFs has improved remarkably in Bangladesh, improved slightly in India, improved modestly in Sri Lanka, but worsened noticeably in Pakistan. This study adds to our knowledge of factors that affect the dynamics of foreign capital inflow, which should be helpful in devising strategies to attract more foreign capital to developing countries.
\end{abstract}

Keywords: Bangladesh, business environment, Enterprise Surveys, foreign-owned firms, India, Pakistan, South Asia, Sri Lanka

\section{Introduction}

Global investors use foreign direct investment (FDI) as a means to secure controlling interest in a foreign business enterprise via acquiring ownership of capital. The World Development Indicators defines FDI as “... a category of cross-border investment associated with a resident in one economy having control or a significant degree of influence on the management of an enterprise that is resident in another economy. Ownership of 10 percent or more of the ordinary shares of voting stock is the criterion for determining the existence of a direct investment relationship" (World Bank 2017a).

In addition to serving the financial interests of foreign investors, FDI can also play a vital role in economic development of developing countries. The FDI literature contends that FDI can help the host countries achieve economic development by alleviating several "development gaps". For example, FDI provides capital for domestic investment, which fills the "investment gap"; FDI provides foreign currency, which fills the "foreign exchange gap"; and FDI generates tax revenues by creating jobs, which closes the "tax revenue gap" (Smith 1997). Many studies have also found that FDI can also help generate domestic investment in matching funds, facilitate transfer of technological knowledge, increase global market access for export commodities, etc.

Due to a variety of factors (for example, revolution in information and communication technologies, greater integration of capital markets due to globalization, etc.), developing countries have opened up to foreign capital since the early 1980s. As a result, the annual FDI inflows to developing countries have increased from \$23 billion in 1990 to about $\$ 646$ billion in 2016 (UNCTAD 2017). There are four countries in South Asia (namely Bangladesh, India, Pakistan and Sri Lanka) that have benefited from higher FDI inflows over the last several decades. These countries, led by India, have witnessed a massive rise in their annual FDI inflows from a meager $\$ 0.55$ billion (0.1\% of combined GDP) in 1990 to nearly $\$ 50$ billion in 2016 (1.8\% of combined GDP) (World Bank 2017a). Table 1 below presents total FDI inflows and average FDI/GDP statistics for these countries over 1972-2016. 
Table 1. FDI Inflows to the Sample Countries

\begin{tabular}{lcc}
\hline Country & Total FDI Inflow (1972-2016) & Average FDI/GDP (1972-2016) \\
\hline Bangladesh & \$20.21 billion & $0.38 \%$ \\
\hline India & \$409.76 billion & $0.77 \%$ \\
\hline Pakistan & \$40.61 billion & $0.78 \%$ \\
\hline Sri Lanka & \$11.30 billion & $0.94 \%$ \\
\hline
\end{tabular}

Source: World Development Indicators, World Bank (2017a)

This article studies the FOFs' perspectives about selected indicators of business environment in Bangladesh, India, Pakistan and Sri Lanka. Using the World Bank's Enterprise Survey 2017 data, this study identifies several barriers - political instability, poor infrastructure, and pervasive corruption, as the biggest obstacles that FOFs face in their business operations in these countries. The other pressing obstacles include inadequately educated workforce, customs and trade regulations, crime, theft and disorder, tax administration, business licensing and permits, and access to finance. Comparing the results with a previous study (Quazi and Quddus 2009), this present study also finds that since 2007 the business environment for FOFs has improved remarkably in Bangladesh, improved slightly in India, improved modestly in Sri Lanka, but worsened noticeably in Pakistan.

The rest of the paper is organized as follows: section 2 provides a review of the literature, section 3 discusses the data and methodology, section 4 presents the results, and the concluding section 5 provides a brief discussion of the policy implications of the findings of this study.

\section{Literature Review}

There is a sizable literature on the determinants of FDI. Many studies have identified domestic economic environment, market size, infrastructure, labor cost, economic openness, political stability, etc. among the key variables that determine the levels of FDI. For example, Schneider and Frey (1985), Wheeler and Mody (1992), Tuman and Emmert (1999) and Cheng and Kwan (2000) found that domestic market size is a significant determinant of FDI; Schneider and Frey (1985) and Noorbakhsh et al (2001) found that higher level of human capital (which is a good indicator for the availability of skilled workers) boosts the locational appeal of a host country, which attracts more FDI; Barro (1991), Corbo and Schmidt-Hebbel (1991), Tuman and Emmert (1999) and Lehmann (1999) found that political instability deters FDI by creating a uncertain economic environment detrimental to long-term planning. Quazi (2007) found that FDI is negatively affected by policy changes that reduce economic freedom, and inefficient financial markets and excessive bureaucracy have created locational disadvantages for Mexico vis-à-vis other countries in Latin America.

Several studies have analyzed the determinants of FDI in South Asia. For example, using 1995-2000 panel data for five South Asian countries (Bangladesh, India, Nepal, Pakistan and Sri Lanka), Quazi and Mahmud (2006) found that economic freedom, trade openness, market size, human capital, incremental lagged changes in FDI, and political stability significantly affect FDI in this region. Using 1975-2003 panel data for the same group of countries, Sahoo (2006) found that market size, labor force growth, infrastructure and trade openness are the significant determinants of FDI. Quazi and Quddus (2009) used 1995-2004 panel data from Bangladesh, India, Pakistan and Sri Lanka and found that FDI is boosted by foreign investors' increased familiarity with the host economy, better infrastructure, market size, human capital, economic freedom, and political stability; FDI is also negatively correlated with restrictive trade policies, government control of the economy, restrictive foreign investment code, repressive financial system, price and wage controls, lax enforcement of property rights, excessive regulation, and restrictive informal market policies. Using the Enterprise Surveys 2007 data, Quazi and Quddus (2009) also found that several hurdles (poor infrastructure, pervasive corruption, crime and disorder, underdeveloped financial markets, excessive regulations, and inadequate human capital) may have created locational disadvantages for Bangladesh in attracting FDI vis-à-vis the other three countries in the sample.

This present study makes a new contribution to the literature by comparing the results from the present study with the results from Quazi and Quddus (2009) to show how the FOFs' perspectives about the business environment in the sample countries have changed since 2007, as well as how the FDI inflows to these countries have changed during the same period. This knowledge should be helpful to policymakers in these countries in devising the appropriate set of strategies to attract more foreign investment, which should also contribute to their economic development. 


\section{Data and Methodology}

This study uses data from Enterprise Surveys (ES), which is published by the Enterprise Analysis unit of the World Bank. Since the 1990s, different units in the World Bank group have conducted firm-level surveys, which has been consolidated since 2005-06 within the Enterprise Analysis Unit. The ES data is described as “... a firm-level survey of a representative sample of an economy's private sector. The surveys cover a broad range of business environment topics including access to finance, corruption, infrastructure, crime, competition, and performance measures" (World Bank 2017b). The ES now offers data on 131,000 firms in 139 countries. The data capture business firms' perceptions on the biggest obstacles to business growth and the relative importance of various constraints to business operations.

The survey follows the ES Global Methodology, which is described in details at the ES website (http://www.enterprisesurveys.org/methodology). The $E S$ surveys are conducted by private contractors hired by the World Bank (instead of agencies or institutions affiliated with local governments), which ensures greater degree of participation, and confidentiality of the data. The survey is usually completed by business owners and top-level management in face-to-face interviews. The number of interviews conducted depends on the size of the economy - about 1,200-1,800 interviews in larger economies, about 360 interviews in medium-sized economies, and about 150 interviews in smaller economies. Registered companies with at least 5 employees are eligible to participate in the survey, and firms with $100 \%$ state ownership are excluded from it.

The most important part of the ES survey is the core survey, which comprises two parts - the first part seeks respondents' opinions on the main obstacles in the business environment, and the second part focuses on productivity measures. The survey questionnaire includes topics related to "firm characteristics, gender participation, access to finance, annual sales, costs of inputs/labor, workforce composition, bribery, licensing, infrastructure, trade, crime, competition, capacity utilization, land and permits, taxation, informality, business-government relations, innovation and technology, and performance measures" (World Bank 2017b).

Although the ES surveys capture data for both domestic and FOFs, this present study uses data from only the FOFs (i.e. firms that have at least $10 \%$ foreign ownership). The year of survey (in parentheses) and the number of FOFs for the sample countries are as follows: Bangladesh (2013) - 35, India (2014) - 85, Pakistan (2013) - 38, and Sri Lanka (2011) - 30.

The next section (Tables 2-12) presents various statistics that capture the FOFs' perspective about a number of constraints (e.g. political instability, corruption, crime, infrastructure, etc.) that affect their business operations in the sample countries. Also, comparisons are made with results found in Quazi and Quddus (2009).

\section{Results from Enterprise Surveys 2017}

Table 2 presents several interesting characteristics for the FOFs in the sample countries. Sri Lanka has the oldest firms (in terms of the age of the establishment), Pakistan has the highest percentage of firms with domestic and government ownership, Bangladesh has the highest percentage of firms registered as sole proprietors, and India has the highest percentage of firms that adhere to international standards of quality certification and external audits.

Table 2. FOF Characteristics

\begin{tabular}{|c|c|c|c|c|}
\hline Firm Characteristics & Bangladesh & India & Sri Lanka & Pakistan \\
\hline Age of the establishment (years) & 18.4 & 16.5 & 27.7 & 24.0 \\
\hline Proportion of private domestic ownership in a firm (\%) & 18.6 & 29.3 & 36.4 & 57.5 \\
\hline$\%$ of firms with at least $10 \%$ of government/state ownership & 0.8 & 0.6 & 1.1 & 24.6 \\
\hline$\%$ of firms with legal status of Sole Proprietorship & 24.4 & 7.5 & 12.6 & 0.0 \\
\hline $\begin{array}{l}\% \text { of firms with an internationally-recognized quality } \\
\text { certification }\end{array}$ & 42.6 & 84.0 & 51.2 & 52.7 \\
\hline $\begin{array}{l}\% \text { of firms with an annual financial statement reviewed by } \\
\text { external auditors }\end{array}$ & 82.3 & 98.0 & 90.5 & 78.9 \\
\hline
\end{tabular}

Table 3 below presents a summary of the top 5 hurdles that the FOFs identified as the biggest obstacles to their business operations. The number in the parenthesis below a hurdle indicates the percentage of FOFs that identified the hurdle as their biggest hurdle. For example, 39.4\% of the FOFs in Bangladesh identified political instability as the biggest hurdle to their business operations, while $6.1 \%$ of FOFs in Bangladesh identified customs and trade regulations as the biggest obstacle to their business operations, and so on. Three hurdles are identified among the biggest hurdles in all four sample countries - political instability (Bangladesh - \#1, India \#4, Sri Lanka - \#5, and Pakistan - \#3), electricity (Bangladesh - \#2, India - \#3, Sri Lanka - \#2, and Pakistan - \#2) and corruption (Bangladesh - \#4, India - \#2, Sri Lanka - \#1, and Pakistan - \#5). Taking the weighted averages of 
these numbers for all fours countries, it appears that the three biggest hurdles to FOFs' business operations are (in order) - political instability (16.60\%), corruption (15.82\%) and electricity (14.85\%).

Table 3. Biggest Obstacles Identified by FOFs

\begin{tabular}{|c|c|c|c|c|c|}
\hline & $\begin{array}{c}\text { Biggest } \\
\text { Obstacle \#1 }\end{array}$ & $\begin{array}{c}\text { Biggest } \\
\text { Obstacle \#2 }\end{array}$ & $\begin{array}{c}\text { Biggest } \\
\text { Obstacle \#3 }\end{array}$ & $\begin{array}{c}\text { Biggest } \\
\text { Obstacle \#4 }\end{array}$ & $\begin{array}{c}\text { Biggest } \\
\text { Obstacle \#5 }\end{array}$ \\
\hline Bangladesh & $\begin{array}{c}\text { Political } \\
\text { instability } \\
(39.4 \%)\end{array}$ & $\begin{array}{l}\text { Electricity } \\
(19.4 \%)\end{array}$ & $\begin{array}{c}\text { Inadequately educated } \\
\text { workforce }(18.4 \%)\end{array}$ & $\begin{array}{l}\text { Corruption } \\
(16.0 \%)\end{array}$ & $\begin{array}{l}\text { Customs and trade } \\
\text { regulations }(6.1 \%)\end{array}$ \\
\hline India & $\begin{array}{l}\text { Access to land } \\
\quad(47.5 \%)\end{array}$ & $\begin{array}{l}\text { Corruption } \\
(13.7 \%)\end{array}$ & Electricity $(7.3 \%)$ & $\begin{array}{l}\text { Political instability } \\
(7.2 \%)\end{array}$ & $\begin{array}{l}\text { Crime, theft and } \\
\text { disorder }(7.1 \%)\end{array}$ \\
\hline Sri Lanka & $\begin{array}{l}\text { Corruption } \\
(34.3 \%)\end{array}$ & $\begin{array}{l}\text { Electricity } \\
(14.0 \%)\end{array}$ & $\begin{array}{l}\text { Business licensing and } \\
\text { permits }(12.8 \%)\end{array}$ & $\begin{array}{l}\text { Tax administration } \\
(12.5 \%)\end{array}$ & $\begin{array}{l}\text { Political instability } \\
\qquad(9.4 \%)\end{array}$ \\
\hline Pakistan & $\begin{array}{c}\text { Access to } \\
\text { finance }(35.0 \%)\end{array}$ & $\begin{array}{l}\text { Electricity } \\
(28.2 \%)\end{array}$ & $\begin{array}{l}\text { Political instability } \\
\qquad(22.3 \%)\end{array}$ & $\begin{array}{c}\text { Tax administration } \\
(6.0 \%)\end{array}$ & Corruption (5.8\%) \\
\hline
\end{tabular}

Table 4 below presents statistics that capture the FOFs' perspective about corruption in the sample countries. The numbers suggest that the FOFs in Bangladesh and Pakistan face much higher incidence of corruption compared against their peers in India and Sri Lanka. It is very common for FOFs in Bangladesh to face the expectation of giving "gifts" (e.g. bribery) to get any type of license or permit or utility connection. In Pakistan, a very high percentage of FOFs identified corruption and the courts system as major constraints. It appears that although the incidence of corruption is fairly low in India and Sri Lanka compared with Bangladesh and Pakistan, however a large proportion of FOFs there identified corruption as a major constraint. Furthermore, per the numbers presented in Table 3, corruption is identified as the biggest obstacle and the second biggest obstacle by FOFs in Sri Lanka and India, respectively. It appears that although corruption is pervasive in Bangladesh and Pakistan, but there are other constraints (such as chronic political instability and inadequate electricity) that are regarded by FOFs as more pressing obstacles.

Table 4. FOFs and Corruption

\begin{tabular}{|c|c|c|c|c|}
\hline Corruption & Bangladesh & India & Sri Lanka & Pakistan \\
\hline $\begin{array}{l}\text { Bribery incidence (\% of firms experiencing at least one } \\
\text { bribe payment request) }\end{array}$ & 83.3 & 15.9 & 4.7 & 52.5 \\
\hline $\begin{array}{l}\text { Bribery depth (\% of public transactions where a gift or } \\
\text { informal payment was requested) }\end{array}$ & 61.5 & 14.8 & 3.1 & 33.4 \\
\hline $\begin{array}{l}\% \text { of firms expected to give gifts in meetings with tax } \\
\text { officials }\end{array}$ & 36.4 & 14.7 & 1.6 & 48.9 \\
\hline $\begin{array}{l}\% \text { of firms expected to give gifts to get an operating } \\
\text { license }\end{array}$ & 90.9 & 24.4 & $\cdots$ & $\ldots$ \\
\hline$\%$ of firms expected to give gifts to get an import license & 100 & 0 & $\ldots$ & $\ldots$ \\
\hline $\begin{array}{l}\% \text { of firms expected to give gifts to get a construction } \\
\text { permit }\end{array}$ & 19 & 5.3 & 12.4 & $\ldots$ \\
\hline $\begin{array}{l}\% \text { of firms expected to give gifts to get an electrical } \\
\text { connection }\end{array}$ & 76.1 & 6.7 & $\cdots$ & $\cdots$ \\
\hline $\begin{array}{l}\% \text { of firms expected to give gifts to public officials "to get } \\
\text { things done" }\end{array}$ & 74.5 & 16.9 & 13.6 & 43.6 \\
\hline$\%$ of firms identifying corruption as a major constraint & 37.3 & 32.4 & 46.1 & 71.5 \\
\hline $\begin{array}{l}\% \text { of firms identifying the courts system as a major } \\
\text { constraint }\end{array}$ & 6.7 & 18.8 & 1.7 & 48.7 \\
\hline
\end{tabular}

Table 5 shows that all FOFs in Bangladesh pay for security and a very low percentage of firms identify crime, theft and disorder as a major constraint, but the situation is exactly the opposite in Pakistan, with fewer than half of the FOFs paying for security and a higher percentage identifying crime, theft and disorder as a major constraint. 
Table 5. FOFs and Crime, Theft and Disorder

\begin{tabular}{lcccc}
\hline Crime, Theft and Disorder & Bangladesh & India & Sri Lanka & Pakistan \\
\hline \% of firms paying for security & 100.0 & 72.4 & 88.2 & 46.6 \\
$\begin{array}{l}\text { \% of firms experiencing losses due to theft and vandalism } \\
\text { \% of firms identifying crime, theft and disorder as a major } \\
\text { constraint }\end{array}$ & 13.6 & 1.6 & 15.9 & 7.9 \\
\hline
\end{tabular}

Table 6 shows that a high percentage of FOFs in all four countries experience frequent electrical outages and have to rely on generators as alternative source of electricity. These numbers are consistent with the numbers presented in Table 3, where electricity was identified among the biggest hurdles in all four countries (Bangladesh - \#2, India - \#3, Sri Lanka - \#2, and Pakistan - \#2). It appears that the state of infrastructure (except water) is the worst in Pakistan, which will likely improve in the coming years due to the huge amounts of Chinese investment in infrastructure projects (especially in electricity and transport) in the China-Pakistan Economic Corridor to support the One Belt One Road initiative, which was launched in 2013 as a key driver of China's new global initiative (UNCTAD 2017).

Table 6. FOFs and Infrastructure

\begin{tabular}{|c|c|c|c|c|}
\hline Infrastructure & Bangladesh & India & Sri Lanka & Pakistan \\
\hline$\%$ of firms experiencing electrical outages & 55.9 & 68.0 & 53.8 & 97.9 \\
\hline $\begin{array}{l}\text { If there were outages, average losses due to electrical } \\
\text { outages ( } \% \text { of annual sales) }\end{array}$ & 5.4 & 0.8 & 2.3 & 23.2 \\
\hline$\%$ of firms owning or sharing a generator & 77.3 & 61.1 & 49.4 & 83.0 \\
\hline$\%$ of firms identifying electricity as a major constraint & 22.2 & 12.6 & 36.4 & 66.3 \\
\hline$\%$ of firms experiencing water insufficiencies & 0.8 & 18.5 & 31.3 & 7.3 \\
\hline$\%$ of firms identifying transportation as a major constraint & 5.7 & 11.7 & 12.0 & 41.7 \\
\hline
\end{tabular}

Table 7 shows that a very high percentage of FOFs in India (94.1\%) use banks to finance investments and more than half of the investment projects are financed by banks, but the FOFs in the other three countries generally rely more on internal resources to finance investment projects. A relatively high percentage of FOFs in Bangladesh rely on banks to finance working capital.

Table 7. FOFs and Access to Finance

\begin{tabular}{|c|c|c|c|c|}
\hline Access to Finance & Bangladesh & India & Sri Lanka & Pakistan \\
\hline$\%$ of firms using banks to finance investments & 14.9 & 94.1 & 28.2 & 52.3 \\
\hline Proportion of investments financed internally & 64.5 & 24.2 & 68.4 & 62.3 \\
\hline Proportion of investments financed by banks & 3.0 & 52.9 & 27.4 & 15.7 \\
\hline$\%$ of firms using banks to finance working capital & 68.8 & 37.7 & 48.3 & 16.6 \\
\hline $\begin{array}{l}\% \text { of firms using supplier/customer credit to finance } \\
\text { working capital }\end{array}$ & 6.1 & 25.3 & 12.2 & 12.4 \\
\hline Proportion of working capital financed by banks & 31.3 & 18.3 & 26.8 & 1.4 \\
\hline $\begin{array}{l}\% \text { of firms identifying access to finance as a major } \\
\text { constraint }\end{array}$ & 0.7 & 14.2 & 17.6 & 2.0 \\
\hline
\end{tabular}

Table 8 below shows that less than $5 \%$ of senior management time of FOFs in all four countries is spent in dealing with the requirements of government regulation, but a high percentage of FOFs (except India) visit or are required to meet with tax officials. A relatively high share of FOFs in Pakistan identified tax rates and tax administration as major constraints.

Table 8. FOFs and Regulations and Taxes

\begin{tabular}{|c|c|c|c|c|}
\hline Regulations and Taxes & Bangladesh & India & Sri Lanka & Pakistan \\
\hline $\begin{array}{l}\text { Senior management time spent dealing with the } \\
\text { requirements of government regulation }(\%)\end{array}$ & 4.4 & 1.5 & 2.7 & 4.8 \\
\hline$\%$ of firms visited or required to meet with tax officials & 79.2 & 36.5 & 63.7 & 78.4 \\
\hline $\begin{array}{l}\text { If there were visits, average number of visits or required } \\
\text { meetings with tax officials }\end{array}$ & 4.9 & 2.0 & 4.4 & 3.5 \\
\hline$\%$ of firms identifying tax rates as a major constraint & 0.8 & 17.0 & 18.3 & 39.4 \\
\hline $\begin{array}{l}\% \text { of firms identifying tax administration as a major } \\
\text { constraint }\end{array}$ & 9.8 & 12.1 & 26.0 & 56.3 \\
\hline $\begin{array}{l}\% \text { of firms identifying business licensing and permits as a } \\
\text { major constraint }\end{array}$ & 11.8 & 12.2 & 13.9 & 14.9 \\
\hline
\end{tabular}

Table 9 shows that a high percentage of FOFs in all four countries use technology (e.g. they have their own website and use emails to communicate with clients/suppliers) and are generally engaged in innovation (e.g. introduced a new product/service or process innovation). 
Table 9. FOFs and Innovation and Technology

\begin{tabular}{|c|c|c|c|c|}
\hline Innovation and Technology & Bangladesh & India & Sri Lanka & Pakistan \\
\hline$\%$ of firms having their own website & 85.5 & 93.7 & 89.1 & 86.9 \\
\hline$\%$ of firms using e-mail to interact with clients/suppliers & 95.1 & 98.0 & 99.2 & 59.6 \\
\hline$\%$ of firms that introduced a new product/service & 74.0 & 73.0 & 39.7 & 37.1 \\
\hline$\%$ of firms that introduced a process innovation & 87.1 & 74.9 & 59.9 & 75.1 \\
\hline
\end{tabular}

Table 10 below shows that most of the FOFs in Bangladesh sell their products to the global market through direct exports, and in contrast, the FOFs in the other three countries sell most of their products to the local markets. The number of days it takes for FOFs to clear exports and imports through customs is the highest in Pakistan.

Table 10. FOFs and Trade

\begin{tabular}{lcccc}
\hline Trade & Bangladesh & India & Sri Lanka & Pakistan \\
\hline $\begin{array}{l}\text { Days to clear direct exports through customs } \\
\text { \% of firms exporting directly or indirectly (at least 10\% }\end{array}$ & 3.2 & 6.1 & $\ldots$ & 13.0 \\
of sales) & 67.3 & 22.7 & 23.4 & 38.7 \\
Proportion of total sales that are exported directly & 58.3 & 8.0 & 6.8 & 10.6 \\
$\begin{array}{l}\text { Days to clear imports from customs } \\
\text { \% of firms identifying customs and trade regulations as a }\end{array}$ & 9.2 & 7.3 & 6.3 & 10.2 \\
major constraint & 8.0 & 11.6 & 16.9 & 13.5 \\
\hline
\end{tabular}

Table 11 below shows that most FOFs in the sample countries (except India) offer formal training to their workers and most of the production workers are skilled workers in all four countries. A modest percentage of FOFs in Bangladesh and Pakistan identified inadequately educated workers as a major constraint.

Table 11. FOFs and Workforce

\begin{tabular}{|c|c|c|c|c|}
\hline Workforce & Bangladesh & India & Sri Lanka & Pakistan \\
\hline$\%$ of firms offering formal training & 69.3 & 37.8 & 90.4 & 78.5 \\
\hline Proportion of workers offered formal training & 89.1 & 56.8 & 47.2 & 45.2 \\
\hline $\begin{array}{l}\text { Proportion of skilled workers (out of all production } \\
\text { workers) }\end{array}$ & 80.4 & 74.1 & 74.5 & 83.2 \\
\hline $\begin{array}{l}\% \text { of firms identifying labor regulations as a major } \\
\text { constraint }\end{array}$ & 0.9 & 12.4 & 3.1 & 2.1 \\
\hline $\begin{array}{l}\% \text { of firms identifying an inadequately educated } \\
\text { workforce as a major constraint }\end{array}$ & 24.0 & 7.1 & 10.4 & 37.0 \\
\hline
\end{tabular}

Table 12 below shows that a huge gender disparity exists in top level management positions in FOFs in all four countries. However, FOFs in Bangladesh have achieved gender parity (50.2\%) for permanent full-time production worker positions, and near parity (44.9\%) for permanent full-time worker positions (that include both production and non-production type positions). Interestingly, FOFs in Pakistan outperform their peers in the other three countries in terms of employing female top managers, but the FOFs there lag far behind their peers when it comes to employing females in permanent full-time worker positions (including both production and non-production type positions).

Table 12. FOFs and Gender Disparity

\begin{tabular}{|c|c|c|c|c|}
\hline Gender Disparity & Bangladesh & India & Sri Lanka & Pakistan \\
\hline$\%$ of firms with a female top manager & 9.5 & 13.0 & 7.4 & 18.6 \\
\hline$\%$ of permanent full-time workers that are female & 44.9 & 33.5 & 16.1 & 0.5 \\
\hline $\begin{array}{l}\% \text { of permanent full-time production workers that are } \\
\text { female }\end{array}$ & 50.2 & 12.8 & 12.6 & 0.5 \\
\hline $\begin{array}{l}\% \text { of permanent full-time non-production workers that } \\
\text { are female }\end{array}$ & 19.8 & 20.3 & 20.7 & 1.2 \\
\hline
\end{tabular}

\section{Comparison with Results from Quazi and Quddus (2009)}

This section compares the results from this study with the results reported in Quazi and Quddus (2009). Both studies used Enterprise Surveys data to capture FOF's perspective about domestic business environment in the host countries; Quazi and Quddus used data from ES 2007, and the present study used the most up-to-date ES data (Bangladesh - 2013, India - 2014, Pakistan - 2013, and Sri Lanka - 2011). Therefore, by comparing the results from these two studies, we should be able to observe how the business environments and the underlying factors have changed in the sample countries since 2007.

Table 13 below lists ten factors from the ES questionnaire that FOFs identified as major constraints to their business operations. The numbers listed in the 2007 column for each country are from Quazi and Quddus (2009), and the second column for each country is from the present study. The arrow shown in the second column for each country ( $\downarrow$ or $\uparrow$ ) indicates which way the FOFs' response has changed since 2007 . For example, $82.97 \%$ of 
the FOFs in Bangladesh identified electricity as a major constraint in the 2007 survey, which decreased to $22.2 \%$ in the 2013 survey, and $7.32 \%$ of the FOFs in India identified electricity as a major constraint in the 2007 survey, which increased to $12.6 \%$ in the 2014 survey.

Table 13. Comparisons with Results from Quazi and Quddus (2009) - Major Constraints

\begin{tabular}{|c|c|c|c|c|c|c|c|c|}
\hline \multirow{2}{*}{$\begin{array}{l}\% \text { of firms identifying this factor as } \\
\text { a major constraint: }\end{array}$} & \multicolumn{2}{|c|}{ Bangladesh } & \multicolumn{2}{|c|}{ India } & \multicolumn{2}{|c|}{ Sri Lanka } & \multicolumn{2}{|c|}{ Pakistan } \\
\hline & 2007 & 2013 & 2007 & 2014 & 2007 & 2011 & 2007 & 2013 \\
\hline \multirow[b]{2}{*}{ Electricity } & \multirow[b]{2}{*}{82.97} & 22.2 & \multirow{2}{*}{7.32} & 12.6 & \multirow{2}{*}{45.98} & 36.4 & \multirow{2}{*}{38.89} & 66.3 \\
\hline & & $\downarrow$ & & $\uparrow$ & & $\downarrow$ & & $\uparrow$ \\
\hline \multirow{2}{*}{ Transportation } & \multirow{2}{*}{36.17} & 5.7 & \multirow{2}{*}{12.20} & 11.7 & \multirow{2}{*}{28.74} & 12.0 & \multirow{2}{*}{5.56} & 41.7 \\
\hline & & $\downarrow$ & & $\downarrow$ & & $\downarrow$ & & $\uparrow$ \\
\hline \multirow{2}{*}{ Corruption } & \multirow{2}{*}{83.07} & 37.3 & \multirow{2}{*}{31.71} & 32.4 & \multirow{2}{*}{22.99} & 46.1 & \multirow{2}{*}{33.33} & 71.5 \\
\hline & & $\downarrow$ & & $\uparrow$ & & $\uparrow$ & & $\uparrow$ \\
\hline \multirow{2}{*}{ Crime, theft and disorder } & \multirow{2}{*}{49.07} & 3.7 & \multirow{2}{*}{0.00} & 11.5 & \multirow{2}{*}{17.24} & 0.0 & \multirow{2}{*}{22.22} & 21.6 \\
\hline & & $\downarrow$ & & $\uparrow$ & & $\downarrow$ & & $\downarrow$ \\
\hline \multirow{2}{*}{ Access to finance } & \multirow{2}{*}{17.25} & 0.7 & \multirow{2}{*}{19.51} & 14.2 & \multirow{2}{*}{14.94} & 17.6 & \multirow{2}{*}{5.56} & 2.0 \\
\hline & & $\downarrow$ & & $\downarrow$ & & $\uparrow$ & & $\downarrow$ \\
\hline \multirow{2}{*}{ Tax rates and administration } & \multirow{2}{*}{40.02} & 5.3 & \multirow{2}{*}{24.39} & 14.6 & & 22.2 & 4444 & 47.9 \\
\hline & & $\downarrow$ & & $\downarrow$ & 13.19 & $\uparrow$ & 44.44 & $\uparrow$ \\
\hline & & 8.0 & & 11.6 & & 16.9 & & 13.5 \\
\hline Customs \& trade regulations & 21.11 & $\downarrow$ & 17.95 & $\downarrow$ & 17.24 & $\downarrow$ & 38.89 & $\downarrow$ \\
\hline Businecs licencing \& permits & 1527 & 11.8 & 1000 & 12.2 & 230 & 13.9 & 556 & 14.9 \\
\hline Busmess ncensmg \& permits & 45.21 & $\downarrow$ & 10.00 & $\uparrow$ & 2.50 & $\uparrow$ & 5.50 & $\uparrow$ \\
\hline & & 24.0 & & 7.1 & & 10.4 & & 37.0 \\
\hline Labor skill level & 67.57 & $\downarrow$ & 7.50 & $\downarrow$ & 18.39 & $\downarrow$ & 5.56 & $\uparrow$ \\
\hline & & 0.9 & & 12.4 & & 3.1 & & 2.1 \\
\hline Labor regulations & 0.0 & $\uparrow$ & 19.51 & $\downarrow$ & 31.03 & $\downarrow$ & 11.11 & $\downarrow$ \\
\hline & & 11.96 & & 14.03 & & 17.9 & & 31.9 \\
\hline Mean Response & 44.25 & $\downarrow$ & 15.01 & $\downarrow$ & 21.20 & $\downarrow$ & 21.11 & $\uparrow$ \\
\hline
\end{tabular}

The numbers for Bangladesh show remarkable improvement across the board for all factors (except for a minor increase in labor regulations). It is noteworthy that there is a substantial improvement in the FOF's perspective about corruption in Bangladesh (as well as several other factors, including electricity). In the ES 2007 survey, more than $83 \%$ of the FOFs identified corruption as a major constraint, which is not surprising as the 2008 Corruption Perception Index (published by Transparency International) ranked Bangladesh $162^{\text {nd }}$ out of 179 countries (rankings of the other three countries: India - 72, Pakistan - 138 and Sri Lanka - 94). In contrast, in the ES 2013 survey, only 37\% of the FOFs identified corruption as a major constraint in Bangladesh, which is consistent with its improvement in the 2013 Corruption Perception Index (out of 177 countries, Bangladesh 136, India - 94, Pakistan - 127 and Sri Lanka - 91). The rankings in the most recent 2017 Corruption Perception Index are: Bangladesh - 143, India - 81, Pakistan - 117 and Sri Lanka - 91 (out of 180 countries), which shows deterioration in Bangladesh's ranking. Nine out of the ten major constraints have improved in Bangladesh (and the mean response for all ten factors has dropped from 44.25 to 11.96), which overall reflects the emergence a more business-friendly environment for the FOFs in Bangladesh.

In India, the business environment for FOFs appears to have remained steady between 2007 to 2014 . The mean response for all ten factors has improved only slightly from 15.01 to 14.03, and responses to six out of ten factors have improved. However, FOF perspective on crime, theft and disorder has significantly deteriorated (response has jumped from 0.0 in 2007 to 11.5 in 2014). Despite this setback, the overall business environment for FOFs shows a slight improvement.

In Sri Lanka, the business environment for FOFs has modestly improved between 2007 to 2011 . The mean 
response for all ten factors has improved moderately from 21.26 to 17.9 , and responses to six out of ten factors have improved. In contrast to the situation in India, FOF perspective on crime, theft and disorder has significantly improved (response has plummeted from 17.24 in 2007 to 0.0 in 2011). In addition, there is solid improvement in two areas - transportation and labor regulations, but there is deterioration in two areas corruption and business licensing \& permits.

In Pakistan, the business environment for FOFs appears to have worsened noticeably from 2007 to 2013 . The mean response for all ten factors has jumped up from 21.11 to 31.9 , and responses to six out of ten factors have worsened. FOF perspectives have significantly deteriorated on a number of constraints - electricity, transportation, corruption, and skilled labor, which does not bode well for the overall business environment in Pakistan.

Table 14 below lists FOF perspectives on seven other factors from the ES that also affect the business environment in the host countries. The numbers show improvements across a wide array of factors since 2007. For example, senior management time spent in dealing with requirements of government regulation and the number of visits/meetings with tax officials have generally decreased, usage of websites and emails to communicate with clients/suppliers have generally increased, incidence of informal payments (bribes) to get things done has generally decreased, access to bank financing for investments has increased, and usage of bank finance to cover expenses has generally decreased.

Table 14. Comparisons with Results from Quazi and Quddus (2009) - Other Factors

\begin{tabular}{|c|c|c|c|c|c|c|c|c|}
\hline \multirow{2}{*}{ Other Factors } & \multicolumn{2}{|c|}{ Bangladesh } & \multicolumn{2}{|c|}{ India } & \multicolumn{2}{|c|}{ Sri Lanka } & \multicolumn{2}{|c|}{ Pakistan } \\
\hline & 2007 & 2013 & 2007 & 2014 & 2007 & 2011 & 2007 & 2013 \\
\hline $\begin{array}{l}\text { Senior management time spent dealing } \\
\text { with requirements of government } \\
\text { regulation }(\%)\end{array}$ & 3.88 & $\begin{array}{c}4.4 \\
\uparrow\end{array}$ & 10.99 & $\begin{array}{c}1.5 \\
\downarrow\end{array}$ & 3.55 & $\begin{array}{c}2.7 \\
\downarrow\end{array}$ & 10.76 & $\begin{array}{c}4.8 \\
\downarrow\end{array}$ \\
\hline $\begin{array}{l}\text { Average number of visits or required } \\
\text { meetings with tax officials }\end{array}$ & 2.18 & $\begin{array}{c}4.9 \\
\uparrow\end{array}$ & 6.32 & $\begin{array}{c}2.0 \\
\downarrow\end{array}$ & 8.66 & $\begin{array}{c}4.4 \\
\downarrow\end{array}$ & 5.35 & $\begin{array}{c}3.5 \\
\downarrow\end{array}$ \\
\hline $\begin{array}{l}\% \text { of firms using the web to communicate } \\
\text { with clients/suppliers }\end{array}$ & 85.22 & $\begin{array}{c}85.5 \\
\uparrow\end{array}$ & 74.36 & $\begin{array}{c}93.7 \\
\uparrow\end{array}$ & 48.28 & $\begin{array}{c}89.1 \\
\uparrow\end{array}$ & 55.56 & $\begin{array}{c}86.9 \\
\uparrow\end{array}$ \\
\hline $\begin{array}{l}\% \text { of firms using email to communicate } \\
\text { with clients/suppliers }\end{array}$ & 100 & $\begin{array}{c}95.1 \\
\downarrow\end{array}$ & 95.0 & $\begin{array}{c}98.0 \\
\uparrow\end{array}$ & 95.4 & $\begin{array}{c}99.2 \\
\uparrow\end{array}$ & 77.78 & $\begin{array}{c}59.6 \\
\downarrow\end{array}$ \\
\hline $\begin{array}{l}\% \text { of firms expected to pay informal } \\
\text { payment (to get things done) }\end{array}$ & 74.91 & $\begin{array}{c}74.5 \\
\downarrow\end{array}$ & 40.0 & $\begin{array}{c}16.9 \\
\downarrow\end{array}$ & 22.78 & $\begin{array}{c}13.6 \\
\downarrow\end{array}$ & 29.41 & $\begin{array}{c}43.6 \\
\uparrow\end{array}$ \\
\hline $\begin{array}{l}\% \text { of firms using banks to finance } \\
\text { investments }\end{array}$ & 14.50 & $\begin{array}{c}14.9 \\
\uparrow\end{array}$ & 29.27 & $\begin{array}{c}94.1 \\
\uparrow\end{array}$ & 18.39 & $\begin{array}{c}28.2 \\
\uparrow\end{array}$ & 11.11 & $\begin{array}{c}52.3 \\
\uparrow\end{array}$ \\
\hline $\begin{array}{l}\% \text { of firms using banks to finance } \\
\text { expenses (working capital) }\end{array}$ & 35.78 & $\begin{array}{c}68.8 \\
\uparrow\end{array}$ & 65.85 & $\begin{array}{c}37.7 \\
\downarrow\end{array}$ & 52.87 & $\begin{array}{c}48.3 \\
\downarrow\end{array}$ & 27.78 & $\begin{array}{c}16.6 \\
\downarrow\end{array}$ \\
\hline
\end{tabular}

Table 15 below presents the average FDI//GDP in the sample countries for two different periods 2000-2007 and 2008-2016. The numbers show that the average FDI/GDP ratio for Bangladesh has increased significantly since 2007, which is in line with the findings of this study (as shown in Table 13) that a more business-friendly environment for the FOFs has emerged in Bangladesh since 2007. The FDI/GDP ratio for India has increased since 2007, which is also consistent with the findings of this study that the overall business environment in India for FOFs has improved (albeit slightly) during that period. The FDI/GDP ratio for Pakistan has dropped significantly since 2007, which is also consistent with the findings of this study that the overall business environment in Pakistan for FOFs has deteriorated during this period. Finally, the FDI/GDP ratio for Sri Lanka has decreased since 2007, but this study found that the business environment for FOFs in Sri Lanka has modestly improved between 2007 to 2011. One possible reason for this discrepancy is that the most recent ES data for Sri Lanka is from 2011, which perhaps does not adequately capture changes to the business environment there during 2011-2016. 
Table 15. Average FDI/GDP in the Sample Countries

\begin{tabular}{lcc}
\hline Country & $\begin{array}{c}\text { Average FDI/GDP } \\
(2000-2007)\end{array}$ & $\begin{array}{c}\text { Average FDI/GDP } \\
(2008-2016)\end{array}$ \\
\hline Bangladesh & 0.56 & 1.25 \\
\hline India & 1.18 & 2.07 \\
\hline Pakistan & 1.58 & 1.06 \\
\hline Sri Lanka & 1.29 & 1.20 \\
\hline
\end{tabular}

Source: World Development Indicators, World Bank (2017a)

\section{Policy Implications and Conclusions}

Based on the results presented in the preceding sections, a set of policy recommendations can be formulated to improve the business environment for the FOFs in the sample countries. This study finds that the three biggest hurdles to FOFs' business operations are (in order) - political instability, corruption, and electricity. The other pressing obstacles include inadequately educated workforce, customs and trade regulations, crime, theft and disorder, tax administration, business licensing and permits, access to finance, and access to land. If most of these hurdles can be successfully alleviated, foreign investors should respond positively to the improved business environment by investing more in the host country (as it was found in the case of Bangladesh since 2007, and in contrast, the opposite scenario has unfolded in Pakistan since 2007).

Although Bangladesh has achieved remarkable progress in improving the FOF business environment, there is further room for improvement in the area of political instability. Nearly $40 \%$ of the FOFs in Bangladesh (and about 22\% of FOFs in Pakistan) identified political instability as the biggest obstacle to their business operations there. Foreign investors are generally risk-averse and seek out host countries for investments that are safe for the long-run security of their investments. Therefore, the host countries should devise strategies that can effectively contain the risk elements, including political instability. Bangladesh and Pakistan have long suffered from episodes of political instability (coupled with military takeovers of state power from democratically elected governments and extremely hostile relationships between the main political parties) that have created the unhealthy legacy of a political landscape that is detrimental to the economy. These countries should take steps to change their culture of confrontational politics, which will help improve the overall economic environment and attract more foreign investment.

Corruption is another big concern for the FOFs, particularly in Sri Lanka. Nearly 35\% of FOFs in Sri Lanka (also $16 \%$ in Bangladesh and 14\% in India) identified corruption as the biggest obstacle to their business operations there. Corruption can deter foreign investment by raising transaction costs of doing business. For example, extra costs arising from paying commissions/bribes for contracts, licenses, permits, utilities connection, tax assessment, etc. raise the overall cost of doing business in a host country. Therefore, these countries should focus on reducing corruption by enforcing the existing anti-corruption policies and/or adopting new strategies, which may be politically difficult in the short run, but these measures will likely bear fruit in the long run by fostering a healthy economic environment that is conducive to attracting more foreign investment.

Access to electricity (which can be regarded as a proxy variable for the state of infrastructure) was identified as the second biggest obstacle to FOFs business operation in three out of the four sample countries (Pakistan - 28\%, Bangladesh - 19\% and Sri Lanka - 14\%), and the third biggest obstacle in India (7\%). The state of infrastructure depends on the availability of electricity supply, water supply, gas supply, telecommunication networks, mobile phone networks, digital networks, roads, highways, airports, seaports, etc., which can significantly affect labor and capital productivity and the locational appeal of a host country. Policymakers in these countries should consider investing more on infrastructure to boost their locational appeal to foreign investors. As discussed already, the One Belt One Road initiative, launched by China in 2013 as a key driver of its new global outreach initiative, presents a good opportunity to South Asia (particularly to Pakistan) to receive huge amounts of Chinese investment in infrastructure projects. Bangladesh and Sri Lanka have recently joined the OBOR initiative, but India has been cautiously staying on the sideline.

This study also finds that since 2007 Bangladesh has achieved remarkable improvement across the board on a number of factors that FOFs view as major constraints to their business operations (for example, corruption, electricity, transportation, etc.). The policymaker in Bangladesh should continue with the policies that have helped with the emergence a more business-friendly environment for the FOFs there. In India, the business 
environment for FOFs appears to have remained steady and business-friendly since 2007. However, the policymakers in India should focus on improving one particular area where the FOF perspective has significantly deteriorated - crime, theft and disorder. In Sri Lanka, the business environment for FOFs has modestly improved since 2007, with solid improvements in transportation and labor regulations. However, the policymakers in Sri Lanka should focus on improving two areas where the FOF perspectives have significantly deteriorated corruption and business licensing \& permits. In Pakistan, the business environment for FOFs appears to have worsened noticeably since 2007. To turn it around, the Pakistani policymaker should focus on improving a number of factors, particularly electricity, transportation, corruption, and skilled labor.

This study adds to our knowledge of factors that drive FDI to the four biggest economies in South Asia (namely, India, Pakistan, Bangladesh, and Sri Lanka). This knowledge should be helpful to policymakers in these countries in devising strategies to attract more foreign investment, which will also contribute to their economic development. Given the intense global competition for foreign capital, there is much at stake in devising the appropriate set of strategies not only for these countries, but also for developing countries as a whole.

\section{References}

Barro, R. (1991). Economic Growth in Cross Section of Countries. Quarterly Journal of Economics, 106(2), 407-444. https://doi.org/10.2307/2937943

Cheng, L. K., \& Kwan, Y. K. (2000). What Are the Determinants of the Location of Foreign Direct Investment? The Chinese Experience. Journal of International Economics, 51, 379-400. https://doi.org/10.1016/S0022-1996(99)00032-X

Corbo, V., \& Schmidt-Hebbel, K. (1991). Public Policies and Saving in Developing Countries. Journal of Development Economics, 36(1), 89-115. https://doi.org/10.1016/0304-3878(91)90006-H

Lehmann, A. (1999). Country Risks and the Investment Activity of U.S. Multinationals in Developing Countries. IMF Working Paper, No. WP/99/133.

Noorbakhsh, F., Paloni, A., \& Youssef, A. (2001). Human Capital and FDI Inflows to Developing Countries: New Empirical Evidence. World Development, 29(9), 1593-1610. https://doi.org/10.1016/S0305-750X(01)00054-7

Quazi, R. (2007). Investment Climate and Foreign Direct Investment: A Study of Selected Countries in Latin America. Global Journal of Business Research, 1(2), 1-14.

Quazi, R., \& Mahmud, M. (2006). Determinants of Foreign Direct Investment in South Asia. The International Journal of Business and Public Administration, 3(1), 1-13.

Quazi, R., \& Quddus, M. (2009). Investment Climate and Foreign Direct Investment: Comparing Bangladesh with Selected Countries in South Asia. Journal of Bangladesh Studies, 11(1), 1-12.

Sahoo, P. (2006). Foreign Direct Investment in South Asia: Policy, Trends, Impact and Determinants. ADB Institute Discussion Paper No. 56.

Schneider, F., \& Frey, B. (1985). Economic and Political Determinants of Foreign Direct Investment. World Development, 13(2), 161-175. https://doi.org/10.1016/0305-750X(85)90002-6

Smart, A., \& Hsu, J. (2004). The Chinese Diaspora, Foreign Investment and Economic Development in China. The Review of International Affairs, 3(4), 544-566.

Smith, S. (1997). Restrictive Policy toward Multinationals: Argentina and Korea. Case Studies in Economic Development, $2^{\text {nd }}$ ed, Upper Saddle River, NJ: Addison Wesley, 178-189.

Transparency International (2013). Corruption Perceptions Index 2013, Berlin: TI.

Transparency International (2017). Corruption Perceptions Index 2017, Berlin: TI. https://www.transparency.org/news/feature/corruption_perceptions_index_2017.

Tuman, J. P., \& Emmert, C. F. (1999). Explaining Japanese Foreign Direct Investment in Latin America, 1979-1992. Social Science Quarterly, 80(3), 539-555.

UNCTAD (2017). World Investment Report 2017, Geneva: UNCTAD. https://doi.org/10.18356/8a599f63-en

Wheeler, D., \& Mody, A. (1992). International Investment Location Decisions: The Case of U.S. Firms. Journal of International Economics, 33(1-2), 57-76. https://doi.org/10.1016/0022-1996(92)90050-T

World Bank (2017a). World Development Indicators 2017, Washington, DC: World Bank. http://databank.worldbank.org/data/reports.aspx?source=world-development-indicators 
World Bank (2017b). Enterprise Surveys 2017, Washington, DC: World Bank, Enterprise Analysis Unit. http://www.enterprisesurveys.org

\section{Copyrights}

Copyright for this article is retained by the author(s), with first publication rights granted to the journal.

This is an open-access article distributed under the terms and conditions of the Creative Commons Attribution license (http://creativecommons.org/licenses/by/4.0/). 